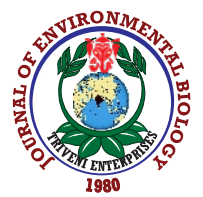

\title{
Genotypic and phenotypic dissection of Xanthomonas oryzae pv. oryzae on Indica rice cultivars for bacterial blight resistance
}

\author{
J. Kumar ${ }^{1,2}$, A. Hussain ${ }^{3}$, P. Singh ${ }^{1,4 *}$, S.K.Y. Baksh', M.K. Kar', A.K. Mukherjee ${ }^{5}$, N.R. Singh', B. Sinha ${ }^{3}$, Pramesh Kh. ${ }^{3}$, N. Singh K. ${ }^{3}$ and J.N. Reddy \\ ${ }^{1}$ Division of Crop Improvement, ICAR-National Rice Research Institute (ICAR-NRRI), Cuttack-753 006, India \\ ${ }^{2}$ Department of Biotechnology, Ravenshaw University, Cuttack-753006, India \\ ${ }^{3}$ Department of Genetics and Plant Breeding, Central Agricultural University, Imphal-791 103, India \\ ${ }^{4}$ Department of Plant Breeding and Genetics, Veer Kunwar Singh College of Agriculture (Bihar Agricultural University), Buxar-802 136, India \\ ${ }^{5}$ Division of Plant Protection, ICAR-National Rice Research Institute (ICAR-NRRI), Cuttack-753006, India \\ *Corresponding Author Email : prakash201288@gmail.com
}

\section{Abstract}

Aim: To evaluate the level of virulence of different $X_{0 o}$ isolates/ pathotypes of Eastern and North-eastern India and to identify the suitable donors in rice cultivars having various $R$-gene combination against virulent $X_{0 o}$ races of Bacterial Blight disease of rice.

Methodology: Thirty six Xoo isolates were collected from different places of Eastern and North-eastern India and genetic diversity/ similarity was examined by genotyping of pathotypes using JEL1/JEL2 markers. The 34 Indica rice cultivars carrying different R-gene combination were selected and grown in net house and inoculated artificially with $X_{00}$ inoculants from these races/isolates bacterial of blight disease.

Results: The selected 36 Xoo isolates of Eastern and North-eastern India were grouped into seven different isolates/ races based on their genetic diversity using JEL1/JEL2 markers. Among 34 Indica rice cultivars, three or more R-gene combination (xa5 + xa13 + Xa21 and/or Xa4 + xa5 + xa13 + $X a 21)$ cultivars exhibited highly resistant as compared to cultivars with single and double gene combination cultivars against most of the $X_{00}$ isolates/races.

Interpretation: The cultivars may determine different level of resistance due to complementary effect of inheritance of suitable R-gene combination. Identified donors may be used for rice resistance breeding programme for Eastern and North-eastern India.

Key words: Bacterial blight, Genetic diversity, Indica rice, Pathotyping, Resistant gene

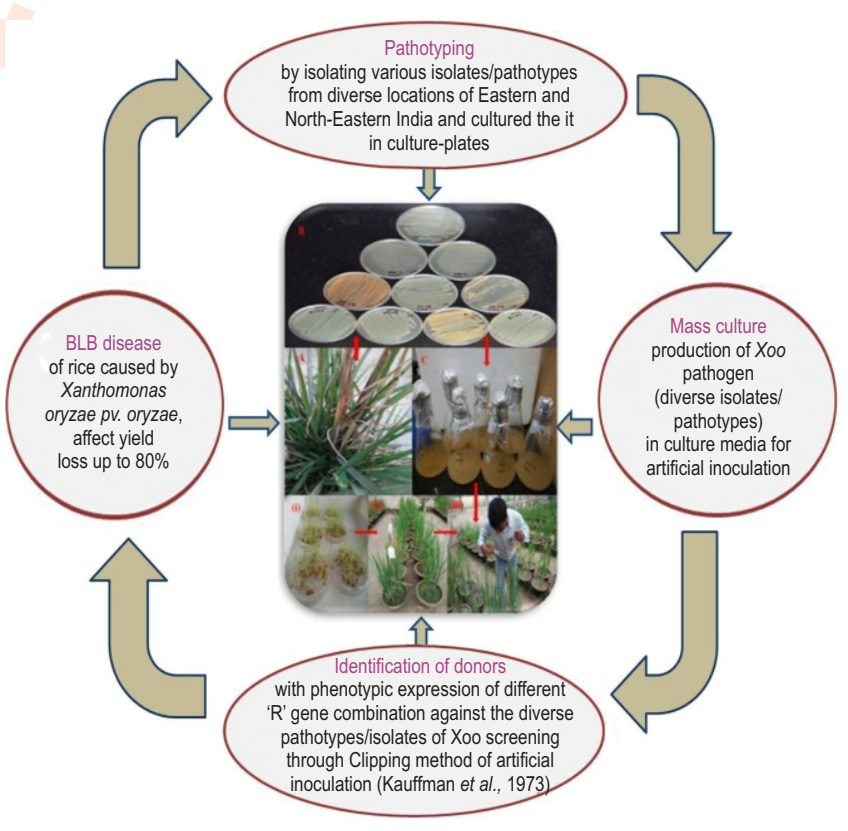

How to cite : Kumar, J., A. Hussain, P. Singh, S.K.Y. Baksh, M.K. Kar, A.K. Mukherjee, N.R. Singh, B. Sinha, Pramesh Kh., N. Singh K. and J.N. Reddy: Genotypic and phenotypic dissection of Xanthomonas oryzae pv. oryzae on Indica rice cultivars for bacterial blight resistance. J. Environ. Biol., 42, 1578-1590 (2021). 


\section{Introduction}

Rice belongs to genus Oryza, of the tribe Oryzeae, and the family Poaceae or Gramineae is an important staple food crop and provide calories as a primary source for more than half of the world's population. Rice production is considerably affected by various biotic factors such fungal, bacterial and viral diseases as well as abiotic factors, i.e., as submergence, drought, salinity, heat, cold etc. Bacterial blight disease of rice is one of the most devastated diseases among all biotic stresses in Asian countries (Wang et al., 1996). It is caused by Gram-negative rod shaped bacterium Xanthomonas oryzae pv. oryzae (Xoo) which affects the yield typically ranging from $20-50 \%$ (Khush et al., 1989), but in severe cases, it can cause $80 \%$ yield reduction (Singh et al., 1977; Singh et al., 2014). Bacterial blight disease was first reported by Japanese farmers in 1884 Fukuoka, in Japan (Ou, 1985; Singh et al., 2020). In order to feed exponentially growing population throughout the globe, farmers are cultivating high yield varieties for cultivation. These high yielding varieties require higher amount of nitrogenous fertilizers.

Excessive use of nitrogenous fertilizers, especially in inorganic forms to maintain the yield of the high yielding varieties is one of the main cause of bacterial blight disease severity (Onasanya et al., 2009). During seedling stage, the disease is termed as 'Kresek' which leads to wilting as well as death of seedlings. If the symptom appears during late tillering stage or at reproductive stage, then it is termed as 'Blight'. It leads to more number of sterile and immature grains. Chemical control of bacterial blight disease in rice is not much effective. Transfer of naturally occurring bacterial blight resistance $(R)$ genes in rice plant is the most effective way of disease control; however, several high yielding rice varieties lack these R- genes. The varietal improvement using R-gene is effective, economical and eco-friendly control strategy for the managing of this disease (Yamamoto et al., 1977; Singh et al., 2020). To date, more than 44 R-genes including some major and some minor which conferring host resistance to various strains/races of $X_{00}$ have been identified in different wild rice and landraces and some have been characterized (Bhasin et al., 2012; Natrajkumar et al., 2012; Suh et al., 2013; Kim et al., 2015; Kim et al., 2019; Singh et al., 2020). Transferring these R-genes using conventional breeding technique is not only a time taking process as well as confirmation of transferred genes in progeny plants may also not be accurate.

Sometimes seasonal dependence for some specific traits is also a barrier. Pyramiding these R-genes in susceptible high yielding rice varieties via marker assisted backcross breeding (MABB) provides a durable and broad-spectrum Bacterial Blight resistance. In India, particularly, Eastern and North-Eastern regions, the household food and nutritional security predominantly depend on rice. However, its production in these areas is drastically reduced by Bacterial Blight disease incidence which is severe due to high humidity and low light intensity. Although a lot of research work has been done on pathotyping and genetic diversity of $X o 0$ races (Shanti et al., 2001; Mondal et al., 2014; Bharath kumar et al., 2014), the effect of different Rgene combination were assessed on different races/ strains of Xoo (Khan et al., 2012; Singh et al., 2014; Singh et al., 2018; Kumar et al., 2019). For improving of locally adapted high yielding but Bacterial Blight disease susceptible cultivars, selection of donor parents with effective R-gene combination against various Xoo races of eastern and north eastern India are mandatory for developing of durable and broad-spectrum Bacterial Blight disease resistant cultivars. Therefore, screening of resistant genes (either dominant or recessive) in combination with more than two resistance genes for Bacterial Blight disease is essential against indigenous $\mathrm{Xoo}$ isolates of the respective regions. In view of the above, the present study was undertaken to detect virulent strain/ races among $X_{0 o}$ isolates of the eastern and north eastern India using pathotyping and to analyze genetic diversity/ similarity though genotyping. Further, in this study, suitable donors/ genotypes with effective R-gene combination against different Xoo isolates/ pathotypes of BB disease present in eastern and north eastern India for Bacterial Blight resistance breeding were also identified.

\section{Materials and Methods}

Experimental setup: Experiment was conducted at ICARNational Rice Research Institute, Cuttack, India during wet season 2014 to 2016. A set of 34 rice genotypes/ near isogenic lines (NILs) carrying different Bacterial Blight resistance genes (R-genes) along with susceptible high yielding varieties (SHYV's) were collected from eastern and north eastern India (Table1). Seeds were thoroughly washed with sterile double distilled water, followed by washing with $70 \%$ ethanol for $30 \mathrm{sec}$ and $0.5 \%$ sodium hypo-chloride for $1 \mathrm{~min}$ to minimize the chance of any seed born contamination. Seeds were sown in sterilized petri plates under plant growth chamber with normal photoperiodic condition to maintain optimum moisture level. Ten-day-old mature healthy seedlings were planted in pots in net house. Finely crushed decayed farmyard manure was spread over the pots and pots were irrigated continuously to maintain proper moisture level. Further, pots were fertilized with urea ( $\left.65 \mathrm{~kg} \mathrm{ha}^{-1}\right)$ in two doses, i.e., $50 \%$ at vegetative stage and $50 \%$ at reproductive stage.

Xoo isolation, maintenance, culture and subculture: Thirty six different Bacterial Blight infected leaf samples (Table2) were collected in separate sterilized $50 \mathrm{ml}$ falcon tubes from 6 states of India, i.e., Manipur, Mizoram, Meghalaya, Sikkim, Tripura and Odisha and stored at $-80^{\circ} \mathrm{C}$. These samples were collected randomly from distant location and were distinct from each other. Bacterial Blight infected leaf samples were aseptically separated by cutting into $1-2 \mathrm{~cm}$ pieces using sterilized scissors and dipped in sterilized double distilled water for $1 \mathrm{hr}$ to collect Xanthomonas oozes in aqueous condition. These aqueous solutions were then used for culturing Xanthomonas colonies into modified ATCC (American type culture collection) medium and the $\mathrm{pH}$ of media was adjusted to 7.00. After autoclaving at $15 \mathrm{psi}$, for $20 \mathrm{~min}$ at $121^{\circ} \mathrm{C}$, the media was allowed to cool at room temperature for a while and poured into pre-sterilized Petri plates and culture 
tubes. Plating of aqueous solution of Xanthomonas in media was done under laminar air flow using aseptic condition followed by incubating the cultures at $25^{\circ} \mathrm{C}$ under normal light condition for growth and multiplication of bacterial colonies. For transportation/long term storage, nutrient broth media or $5 \%$ glycerol was prepared and bacterial colonies were added aseptically to it and stored at $-20^{\circ} \mathrm{C}$. Stored cultures of $X_{00}$ sometimes loose its virulence, therefore to maintain its virulence and pathogenicity, all $\mathrm{X}_{00}$ cultures were inoculated into $\mathrm{TN}-1$ (susceptible check).

Genotyping of Xoo samples and analysis of genetic diversity: Stored Xanthomonas cultures were revived by subculturing on modified ATCC and colonies of pure culture were taken for DNA isolation using modified CTAB method. PCR reaction of bacterial (Xoo) DNA was carried out (George et al., $1995)$ in a $25 \mu$ l reaction mixture. The reaction mixture was prepared with 50 picomole of seach primers (IDT) JEL1 and JEL2
(Table 3) complementary to each end of IS 1112, 20ng of genomic DNA of Xoo, $185 \mu$ Md NTPs mix (Genetix), 2.5 units of Taq polymerase (Kappa Bio-system), 1X PCR buffer-B (Kappa Biosystem), 0.1X DMSO (dimethylsulfoxide) (vol/vol), $7.5 \mu \mathrm{l}$ of Tris$\mathrm{HCl}(\mathrm{pH}$ 9.5) and 1 drop of mineral oil. After PCR amplification, 15 $\mu$ of each PCR products were loaded in a $0.5 \%$ agarose $+0.75 \%$ synergel (Sigma)+0.1ug ethidium bromide $+0.1 \mathrm{X}$ Tris-borateEDTA buffer and $1 \mathrm{~kb}$ DNAladder (thermo Fisher Sc.) was used as reference marker in first lane of gel. Amplified products were resolved by electrophoresis in $0.1 X$ Tris-borate EDTA buffer for 5 $6 \mathrm{hr}$ at 100 Volt, followed by capturing Gel images on Gel Doc (Syngene-ingenious). The banding pattern was scored using binary system of each band in 0 to 1 score, 0 for absence and 1 for presence. For analysis of genetic diversity/similarity, NTSY Spc version 2.02i (Exeter Software Setauket, New York) were used to determine genetic diversity/ similarity between and among $X_{00}$ samples. Binary scoring of Xanthomonas JEL1/JEL2 PCR banding pattern were used to import data into NTSYSpc software and to

Table 1: Rice genotypes/ lines used in the study which consists of near isogenic lines(NILs) and rice differentials containing different R-gene combination of bacterial leaf blight resistance

\begin{tabular}{|c|c|c|}
\hline Genotypes & Feature/gene reported & Sources \\
\hline IRBB3 & Ха3 & \\
\hline IRBB4 & Xa4 & \\
\hline IRBB5 & xa5 & \\
\hline IRBB7 & Xa7 & \\
\hline IRBB8 & xa8 & \\
\hline IRBB10 & Xa10 & \\
\hline IRBB13 & xa13 & \\
\hline IRBB14 & Xa14 & \\
\hline IRBB21 & Xa21 & \\
\hline IRBB50 & Xa4+xa5 & International Rice Research Institute (IRRI), \\
\hline IRBB51 (IR72912.15-1-5) & Xa4+ xa13 & Philippines \\
\hline IRBB52 (IR72913-52-1-4) & $X a 4+X a 21$ & \\
\hline IRBB53 (IR72914-21-1-3) & $x a 5+X a 13$ & \\
\hline IRBB54(IR72915-17-2-4) & $x a 5+X a 21$ & \\
\hline IRBB55 (IR72916-51-1-3) & $x a 13+X a 21$ & \\
\hline IRBB56 (IR72918-37-1-1) & $x a 4+x a 5+x a 13$ & \\
\hline IRBB57 (IR72919-10-1-3) & $X a 4+x a 5+X a 21$ & \\
\hline IRBB58(IR72920-1-99-3) & $X a 4+x a 13+X a 21$ & \\
\hline IRBB59 (IR72920-1-2-40) & $x a 5+x a 13+X a 21$ & \\
\hline IRBB60 (IR72920-1-44-4) & $X a 4+x a 5+x a 13+X a 21$ & \\
\hline Improved PR114 & Xa38 & \\
\hline \multicolumn{3}{|l|}{ Improved Lalat } \\
\hline Improved Tapaswini & Improved high yielding local variety & ICAR-National Rice Research Institute, (NRRI), \\
\hline Improved Ir64 & with $x a 5+x a 13+X a 21$ & Cuttack, Odisha, India \\
\hline \multicolumn{3}{|l|}{ Improved Swarna } \\
\hline Naveen & Susceptible high yielding local variety & \\
\hline Pooja & of Eastern India & \\
\hline CAÚ- R1 & & Central Agricultural University, Imphal, Manipur, India \\
\hline \multicolumn{3}{|l|}{ Shahsarang } \\
\hline Lampnah & Susceptible high yielding variety of & \\
\hline Ranjit & north eastern India & \\
\hline \multicolumn{3}{|l|}{ PD-10 } \\
\hline VL-82 & & \\
\hline TN-1 & Negative control for BB Disease & $\begin{array}{l}\text { ICAR-National Rice Research Institute, (NRRI), } \\
\text { Cuttack Odisha India }\end{array}$ \\
\hline
\end{tabular}


Table 2: Xoo isolates collected from different regions of Eastern and North-eastern India

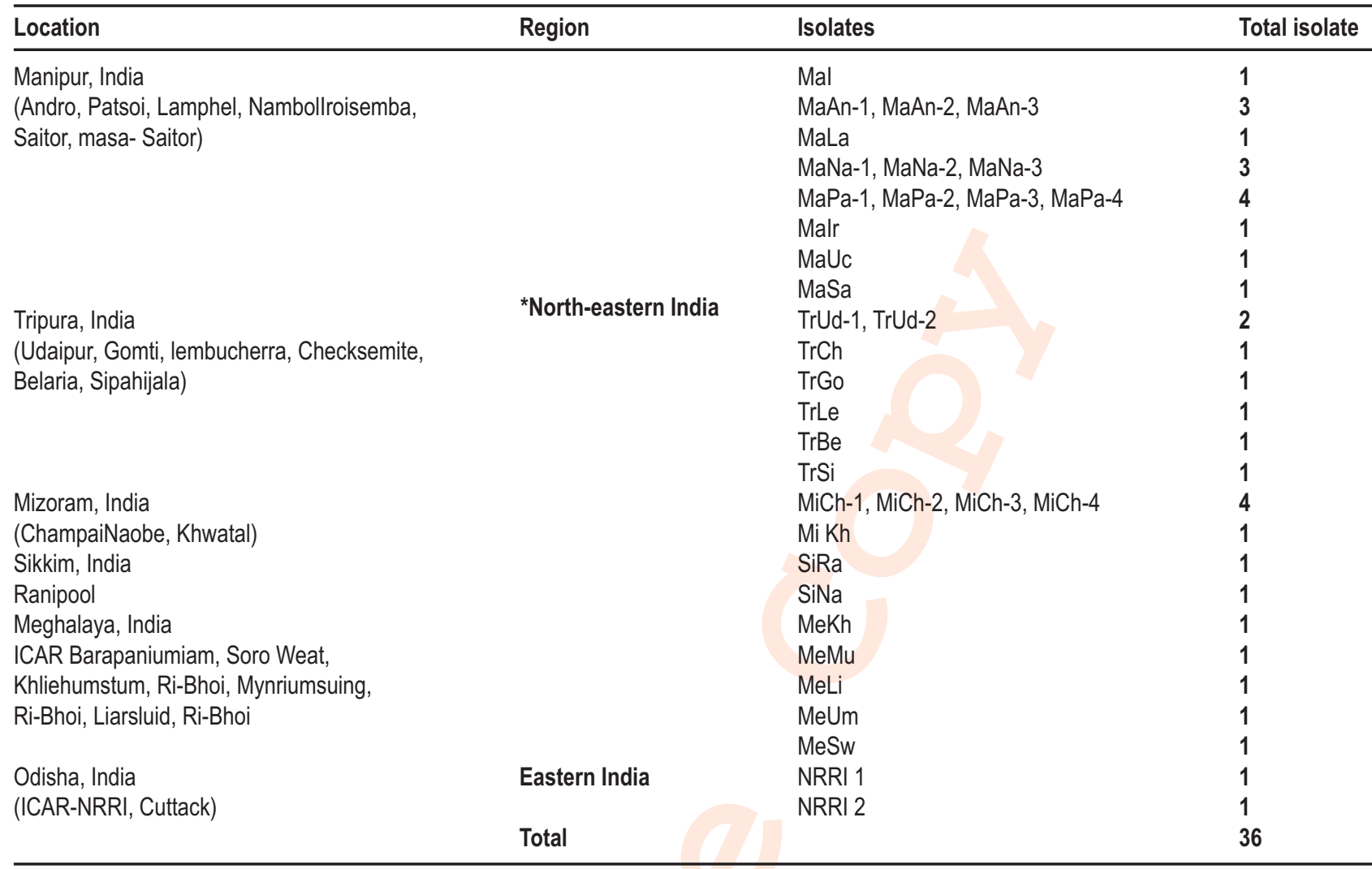

Table 3: Details of molecular markers and their sequence used for genotyping

\begin{tabular}{|c|c|c|c|c|}
\hline Genes & Primers & Sequence 5'-3' & Annealing temperature & References \\
\hline \multirow[t]{2}{*}{ Xa4 } & Npb181-F & ATCGATCGATCTTCACGAGG & 55 & Yoshimura et al. (1995) \\
\hline & Npb181-R & GTGCTATAAAAGGCATTCGGG & & \\
\hline \multirow[t]{2}{*}{ xa5 } & RM122- F & GAGTCGATGTAATGTCATCAGTGC & 55 & Blair, (1997) \\
\hline & RM122-R & GAAGGAGGTATGCCTTTGTTGGAC & & \\
\hline \multirow[t]{2}{*}{ xa13 } & xa13-prom-F & GGCCATGGCTCAGTGTTTAT & 55 & Sundaram et al. (2011) \\
\hline & xa13-prom-R & GAGCTCCAGCTCTCCAAATG & & \\
\hline \multirow[t]{2}{*}{ Xa21 } & pTA248-F & AGACGCGGAAGGGTGGTTCCCGGA & 55 & Ronald et al. (1992) \\
\hline & PTA248-R & AGACGCGGTAATCGAAAGATGAAA & & \\
\hline \multirow[t]{2}{*}{ Ха38 } & Oso4g53050-1 F & TCTTCTATTGCTAACATTGGTG & 55 & Bhasin et al. (2012) \\
\hline & Oso4g53050-1R & TCGCATTCATTTTCAGAG & & \\
\hline \multirow{2}{*}{$\begin{array}{l}\text { Xoo genetic } \\
\text { diversity }\end{array}$} & JEL1 & CTCAGGTCAGGTCGCC3 & 55 & Leach et al. (1992); \\
\hline & JEL2 & GCTCTACAATCGTCCGC & & \\
\hline
\end{tabular}

obtaine dendrogram with similarity coefficient ranging between 0.00 to 1.00. However, for dendrogram prediction, Sequential, Hierarchical, Agglomerative, and Nested Clustering (SAHN) using Unweighted Pair Group Method with Arithmetic Mean (UPGMA) clustering program (Sneath and Sokal, 1973) with Jaccard (J) similarity coefficient were used (Sneath et al., 1973).

\section{Isolation of plant genomic DNA, genotyping and disease}

assessment: Genomic DNA was isolated from healthy leaves of 34 rice genotypes/ NILs (Table1) following the modified CTAB protocol (Doyle and Doyle, 1987). PCR (Eppendorfvapo-protect) reaction was performed to assess the presence of Bacterial Blight resistant genes using primers Npb181-Xa4, RM122- xa5, xa13prom-xa13 gene, pTA248-Xa21 gene and Oso4g53050-1-Xa38 (Table 3 ) in all the lines. PCR reaction mixture of $20 \mu \mathrm{l}$ was consisting of $2 \mu \mathrm{l}$ of $50 \mathrm{ng}$ genomic DNA, $1 \mu$ leach of 10 picomole 
Table 4: PCR amplification results of near isogenic lines (NILs) and other BB resistant/ susceptible high yielding varieties/ lines of eastern and North-eastern India

\begin{tabular}{llllll}
\hline Genotypes & \multicolumn{5}{c}{ R-genes } \\
\cline { 2 - 6 } & Xa4 & xa5 & xa13 & Xa21 & Xa38 \\
\hline IRBB3 & - & - & - & - & - \\
IRBB4 & + & - & - & - & - \\
IRBB5 & - & + & - & - & - \\
IRBB7 & - & - & - & - & - \\
IRBB8 & - & - & - & - & - \\
IRBB10 & - & - & - & - & - \\
IRBB13 & - & - & + & - & - \\
IRBB14 & - & - & - & - & - \\
IRBB21 & - & - & - & + & - \\
IRBB50 & + & + & - & - & - \\
IRBB51 (IR72912.15-1-5) & + & - & + & - & - \\
IRBB52 (IR72913-52-1-4) & + & - & - & + & - \\
IRBB53 (IR72914-21-1-3) & - & + & + & - & - \\
IRBB54(IR72915-17-2-4) & - & + & - & + & - \\
IRBB55 (IR72916-51-1-3) & - & - & + & + & - \\
IRBB56 (IR72918-37-1-1) & + & + & + & - & - \\
IRBB57 (IR72919-10-1-3) & + & + & & + & - \\
IRBB58(IR72920-1-99-3) & + & & + & + & - \\
IRBB59 (IR72920-1-2-40) & - & + & + & + & - \\
IRBB60 (IR72920-1-44-4) & + & + & + & + & - \\
Improved PR114 & - & - & - & - & + \\
Improved Lalat & - & + & + & + & - \\
Improved Tapaswini & - & + & + & + & - \\
Improved IR64 & - & + & + & + & - \\
Improved Swarna & - & + & + & + & - \\
Naveen & - & - & - & - & - \\
Pooja & - & - & - & - & - \\
CAU- R1 & - & - & - & - & - \\
Shahsarang & - & - & - & - & - \\
Lampnah & - & - & - & - & - \\
Ranjit & - & - & - & - & - \\
PD-10 & - & - & - & - & - \\
VL-82 & - & - & - & - & - \\
TN-1 & - & - & - & - & - \\
\hline & & & & \\
\hline
\end{tabular}

forward and reverse primers (IDT), $2 \mu \mathrm{l}$ 10X PCR buffer $\left(\mathrm{MgCl}_{2}\right.$ added), $2 \mu l 10 \mathrm{mM}$ dNTPs mix (Genetix), $0.2 \mu \mathrm{l} 5 \mathrm{U} \mu \mathrm{l}^{-1}$ Taq DNA polymerase (Kappa Bio-system) and nuclease free 11.8ul MilliQ water. After PCR amplification, $15 \mu \mathrm{l}$ of each PCR products were loaded on 2.5 to $3.5 \%$ agarose gel $+10 \mu$ l ethidium bromide $+0.1 \mathrm{X}$ Tris-borate-EDTA buffer. Amplified products were resolved by electrophoresis in 0.1X Tris-borate-EDTA buffer for $4 \mathrm{hr}$ at $100 \mathrm{~V}$ and gel images were captured using gel documentation system (Syngene- ingenious). Scoring of banding pattern (0-1) was done using $1 \mathrm{~kb}$ (Pure-gene) DNAladder as reference size marker.

Different isolates of $X_{00}$ were grouped into different clusters and from each cluster, one representative isolate was taken to make aqueous suspension of bacterial cells. Forty eight hour old cultures were used to prepare inoculums in distilled water and the concentration of bacterial suspension was maintained at $10^{8} \mathrm{CFU} \mathrm{ml}^{-1}$ (1OD). For artificial inoculation, clipping method (Kauffman et al., 1973) was used for inoculating Xoo inoculums in three replications of each genotype (NILs and SHYV's) after 45 days of transplanting or at maximum tillering stage during Kharif season. However, TN-1 was used as negative control for all isolate groups to check the efficiency of Xoo inoculants. The BB disease infestation was recorded by measuring leaf lesion length after 15 days of inoculation and scored for pathotyping. Bacterial Blight disease response for each genotype was classified as resistant, if the mean leaf lesion length was between $0-5 \mathrm{~cm}$, moderately resistant if $>5-10 \mathrm{~cm}$, moderately susceptible if $>10-15 \mathrm{~cm}$ and susceptible if $>15 \mathrm{~cm}$. . The statistical analysis of data generated from molecular markers banding pattern were analyzed by following the procedure of Verma et al., 2017 and Pandey et al., 2020.

\section{Results and Discussion}

Presently, more than 44 R-genes, including major and some minor genes which confer host resistance to various strains/races of Xoo were identified and some were characterized (Chen et al., 2011; Bhasin et al., 2012; Natrajkumar et al., 2012; Suh et al., 2013; Kim et al., 2015; Singh et al., 2020). In order to confirm the presence of reported genes before artificial inoculation of $X o 0$ isolates, PCR reaction was performed for Xa4, xa5, xa13, Xa21 and Xa38 genes for all rice genotypes viz., BB NILs, susceptible and resistance checks, SHYV's and improved resistant varieties. Gel electrophoresis results confirmed the product/ band size of $130 \mathrm{bp}$ to $150 \mathrm{bp}$ for PCR product of npb181-Xa4 gene, 227bp to 239bp for RM122-xa5 gene, 250bp to $500 \mathrm{bp}$ for xa13-prom.-xa13 gene, $750 \mathrm{bp}$ to $1000 \mathrm{bp}$ for pTA248-Xa21 gene and 250bp to 300bp for Oso4g53050-1 of Xa38 gene in IRBB60 (resistant check) and TN-1 (susceptible checks), respectively (Fig. 1.I). Accordingly, PCR screening was performed in all the 34 genotypes and PCR product confirmed the presence of resistant gene Xa4 in IRBB4, $x a 5$ in IRBB5, xa13 in IRBB13, Xa21 in IRBB21 and Xa38 in Improved PR114 (Table 4).

All the five genes ( $X a 4, x a 5, x a 13, X_{a} 21$ and $\left.X a 38\right)$ were found absent in high yielding varieties i.e., Naveen and Pooja of eastern India and CAU-R1, Shahsarang, Lampnah, Ranjit, PD-10 and VL-82 of North-Eastern India and presence of four Bacterial Blight genes was confirmed in IRBB60 i.e., Xa4 + xa5 + xa13 + $X a 21$ gene. However, the presence of 3 Bacterial Blight resistant gene combination, i.e., xa5 + xa13+ Xa21 was confirmed in improved high yielding rice varieties i.e., Imp. Lalat, Imp. Tapaswini, Imp. IR64 and Imp. Swarna and IRBB59. Similarly, the presence of other 3 Bacterial Blight resistant gene combination i.e., $X a 4+x a 5+x a 13$ in IRBB56, Xa4 + xa5 + Xa21 in IRBB57, Xa4 + $x a 13+X a 21$ in IRBB58 were observed. Other two Bacterial Blight resistant gene combinations were present, i.e., $X a 4+x a 5$ in IRBB50, Xa4+ xa13 in IRBB51, Xa4+ Xa21 in IRBB52, xa5+ xa13 in 
Table 5: Distribution of Xoo isolates in Eastern state Odisha and North-eastern states Manipur, Tripura, Mizoram, Sikkim and Meghalaya

\begin{tabular}{|c|c|c|c|c|c|c|c|c|}
\hline \multirow{2}{*}{ Location } & \multirow{2}{*}{ Isolates } & \multicolumn{7}{|c|}{ Pathotype distribution } \\
\hline & & Isolate-I & Isolate-II & Isolate-III & Isolate-IV & Isolate-V & Isolate-VI & Isolate-VII \\
\hline \multirow[t]{15}{*}{ Manipur, India } & Mal & & & & IV & & & \\
\hline & MaAn-1 & & & III & & & & \\
\hline & MaAn-2 & I & & & & & & \\
\hline & MaAn-3 & & & & IV & & & \\
\hline & MaLa & & & III & & & & \\
\hline & MaNa-1 & & & & IV & & & \\
\hline & $\mathrm{MaNa}-2$ & & & III & & & & \\
\hline & MaNa-3 & I & & & & & & \\
\hline & MaPa-1 & & & & IV & & & \\
\hline & $\mathrm{MaPa}-2$ & & & III & & & & \\
\hline & $\mathrm{MaPa}-3$ & & & & IV & & & \\
\hline & MaPa-4 & I & & & & & & \\
\hline & Malr & & & & IV & & & \\
\hline & $\mathrm{MaUc}$ & I & & & & & & \\
\hline & $\mathrm{MaSa}$ & I & & & & & & \\
\hline \multirow[t]{7}{*}{ Tripura, India } & Trud-1 & I & & & & & & \\
\hline & TrUd-2 & I & & & & & & \\
\hline & $\mathrm{TrCh}$ & i & & & & & & \\
\hline & TrGo & & & & IV & & & \\
\hline & TrLe & & & III & & & & \\
\hline & TrBe & I & & & & & & \\
\hline & $\mathrm{TrSi}$ & I & & & & & & \\
\hline \multirow[t]{5}{*}{ Mizoram, India } & MiCh-1 & & & & IV & & & \\
\hline & MiCh-2 & & & & IV & & & \\
\hline & MiCh-3 & & & III & & & & \\
\hline & MiCh-4 & & & III & & & & \\
\hline & Mi Kh & & & III & & & & \\
\hline \multirow[t]{2}{*}{ Sikkim, India } & SiRa & & & & & & & VII \\
\hline & $\mathrm{SiNa}$ & & & & IV & V & & \\
\hline \multirow[t]{5}{*}{ Meghalaya, India } & MeKh & & & & & & & VII \\
\hline & $\mathrm{MeMu}$ & & & & & V & & 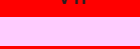 \\
\hline & MeLi & & & & & & & VII \\
\hline & MeUm & & & & & & & VII \\
\hline & $\mathrm{MeSw}$ & & & & & V & & \\
\hline \multirow[t]{2}{*}{ Odisha, India } & NRRI 1 & & & & & & VI & \\
\hline & NRRI 2 & & II & & & & & \\
\hline
\end{tabular}

IRBB53, xa5+Xa21 in IRBB54, xa13+Xa21 in IRBB55. Molecular tools enable us to identify resistant genes/ alleles for different abiotic and biotic traits from germplasm. This modern approach has been utilized to develop resistant crop through breeding programs (Manju et al., 2018; Kim et al., 2019; Singh et al., 2020). In the present study, 36 isolates of Xoo, collected from 5 states of North-East (Manipur, Mizoram, Meghalaya, Sikkim, Tripura) and 1 Eastern state (Odisha) were characterized through PCR based DNA fingerprinting using JEL1/JEL2 marker and virulence analysis. Based on their genetic similarity and diversity, grouping of $36 X_{00}$ isolates were performed through PCR reaction, which showed multiple alleles (Fig. 1.II) and alleles were scored as per binary scoring system. Genetic diversity prediction and dendrogram was made using software NTSYSpc version 2.02i with SAHN-UPGMA clustering and Jaccard similarity coefficient. It exhibited genetic diversity/similarity between and within $\mathrm{Xoo}_{0}$ isolates with similarity coefficient ranging from 0.01 to 1.00 (Fig. 2). Similarity coefficient between two clusters was 0.35 , which means all 36 Xoo isolates were genetically conserved by $35 \%$ and were divided into two main clusters. However, similarity coefficient of 0.44 represented, two clusters divided in four sub-clusters and 0.50 similarity coefficient represented formation of 6 sub clusters and finally, 0.80 similarity coefficient exhibited, that seven groups were obtained.

Based on the results of genetic diversity/ similarity with similarity coefficient of 0.80 , all 36 Xoo isolates were grouped into seven isolate groups (haplotype) ranging from Isolate I to VII (Table 5). Molecular pathotyping enable us for rapid, efficient and precise analysis of virulence by PCR fingerprinting of pathogen 
Table 6A: Graph showing mean length of leaf lesion in several NILs of IR 24, represented as IRBB NILs along with negative checks, i.e., TN-1

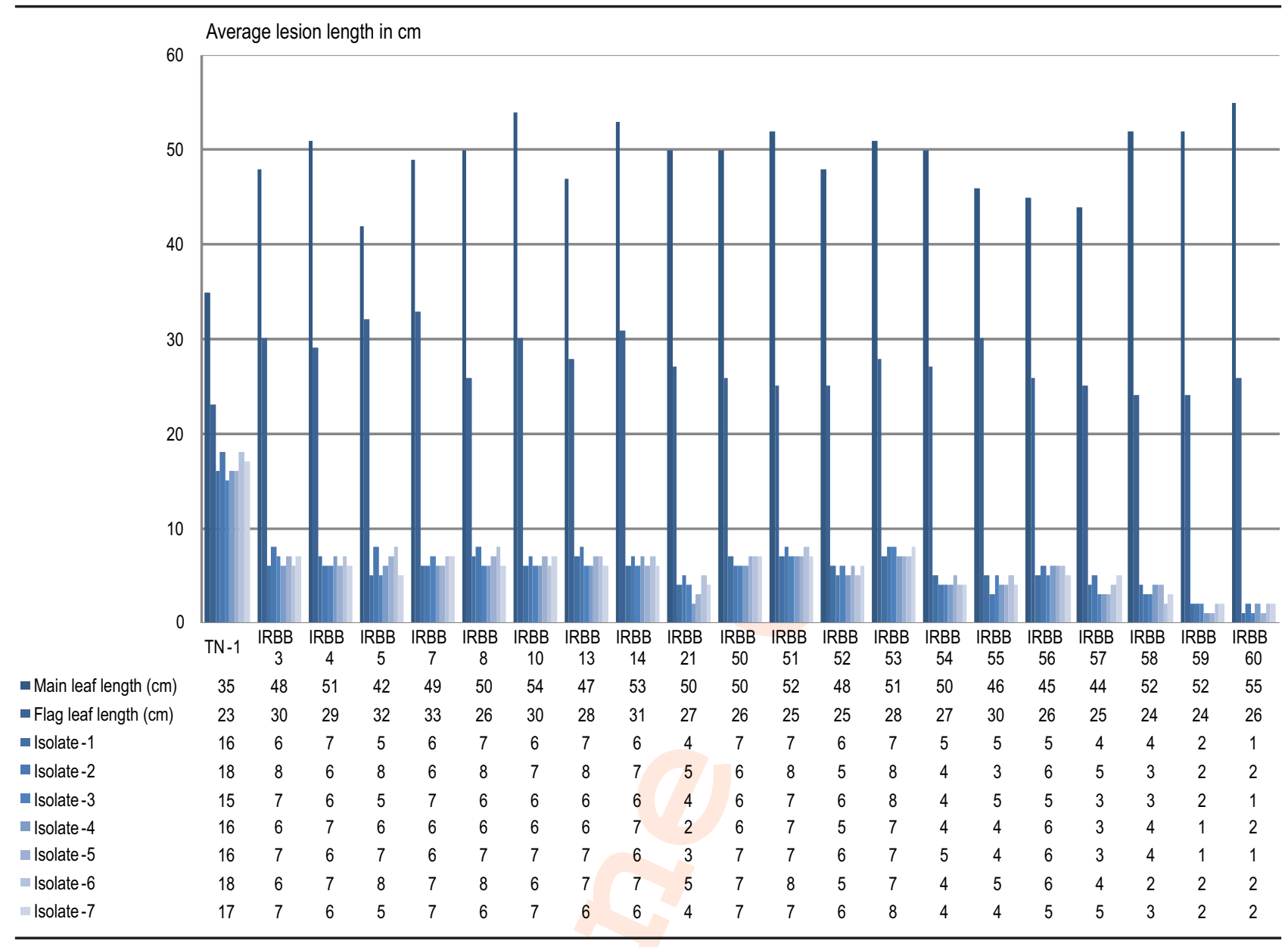

population, by finally limiting the number of isolates for handling. Shanti et al. (2001) reported that, a strong association between RFLP and $X_{00}$ isolate diversity, as well as a relationship among lineages and pathotypes in eastern India. In the present study, similar observation was found in the relationship among lineages and pathotypes in eastern and north-eastern India. The presence Xoo isolates in different states of India were further classified as these isolate were present in particular region such as Isolate I, III and IV was present in Manipur and Tripura region, Isolate III and IV in Mizoram, Isolate IV, V and VII in Sikkim and Isolate V and VII in Meghalaya and Isolate II and Isolate VI in Odisha region. It means several Isolates of $X_{00}$ were found present in northeastern region of India, except Isolate II and VI and some isolate types were found in several regions. However, North-eastern states of India are rich source of genetic diversity in rice germplasm which may lead to genetic diversity in pathogens causing variation in level of disease virulence and resistance. Adhikari et al. (1999) reported that differences in host cultivar have significant role in Xoo pathogen diversity. Xoo strains distributed in several ecosystems which plays a significant role in the differentiation of pathogen population.
The above findings enable us to select representative isolates for identification of suitable R-genes for breeding program of concerning region using artificial inoculation. Artificial inoculation method was applied to determine the response of 34 rice genotypes against seven Isolate groups, representing 36 Xoo Isolates of Eastern and North-Eastern India. The significance Bacterial Blight disease reaction was observed on 34 rice genotypes after inoculating cultures from seven groups of isolates (Table 6A, 6B; Fig. 3). The highest lesion length of 18 $\mathrm{cm}$ was recorded for isolate $\mathrm{Il}$ and $\mathrm{VI}$, however, the remaining five isolates showed $02-17 \mathrm{~cm}$ lesion length against total main and flag leaf length of $35-55 \mathrm{~cm}$ and $23-33 \mathrm{~cm}$, respectively. As compared to the performance of NILs on main leaf / flag leaf length ratio, IRBB59 $(52 \mathrm{~cm} / 24 \mathrm{~cm})$ and IRBB60 $(55 \mathrm{~cm} / 26 \mathrm{~cm})$ showed only $1-2 \mathrm{~cm}$ lesion of Bacterial leaf Blight on all seven isolates. Similarly, 2-5 cm long lesion was recorded in IRBB57 and IRBB58, however, $5 \mathrm{~cm}$ long lesion was observed in IRBB56 $(45 \mathrm{~cm} / 26 \mathrm{~cm})$ for isolate I, III and VII and $6 \mathrm{~cm}$ long lesion was observed in Isolate II, IV, V and VI. The other NILs of IR 24 such as IRBB52, IRBB54 and IRBB55 showed a lesion length of $5-7 \mathrm{~cm}$ in all seven Xoo isolates whereas IRBB4, 
Table 6B: Graph showing average length of leaf lesion in rice bacterial blight differentials, improved varieties, high yielding susceptible varieties of Eastern and North-Eastern India along with TN-1 (negative checks).

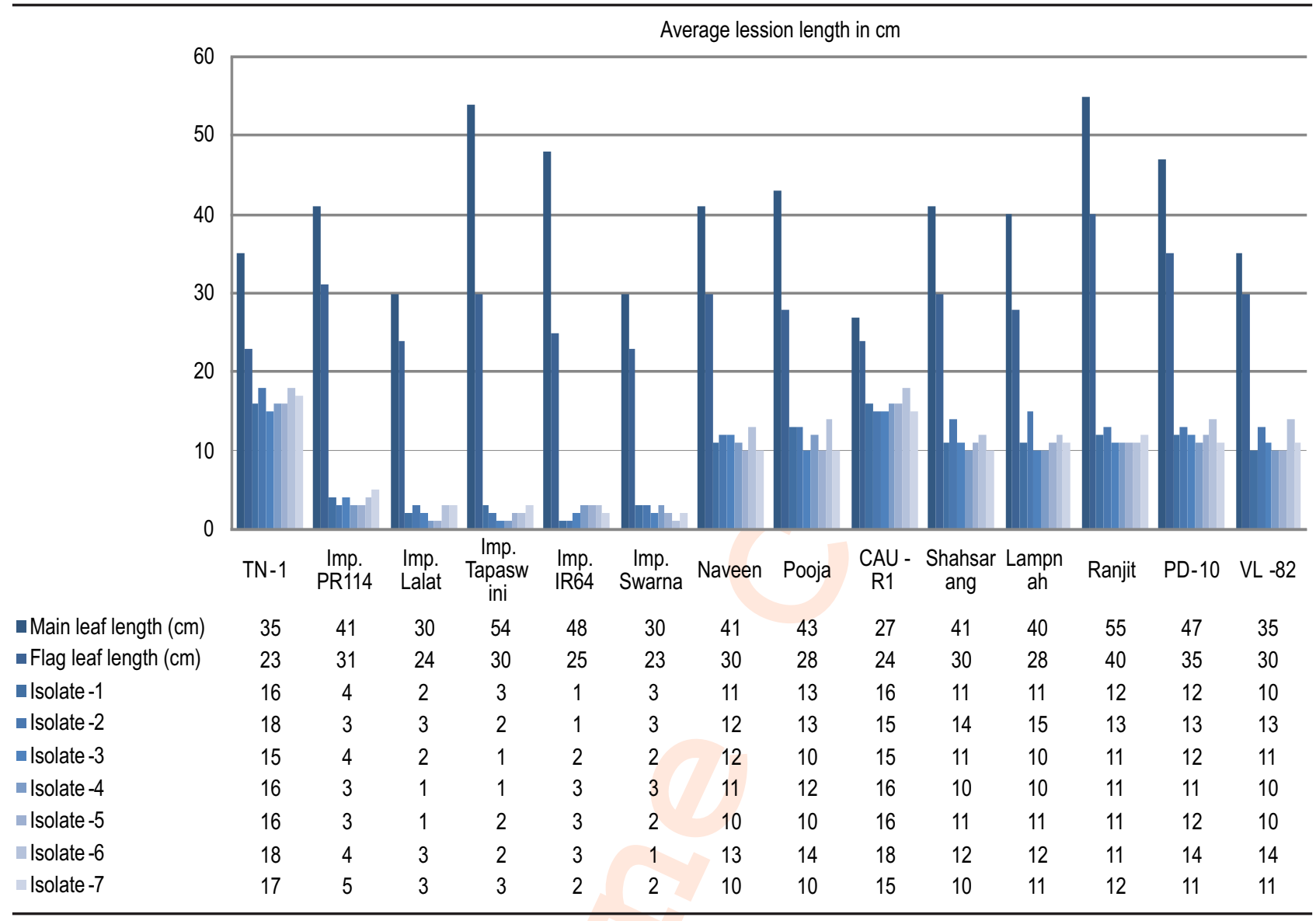

IRBB13, IRBB3, IRBB7, IRBB8, IRBB10 and IRBB14 recorded $6-8 \mathrm{~cm}$ long lesion against all the isolates. The main leaf length/flag leaf length of IRBB21 and Imp. PR114 was $50 \mathrm{~cm} / 20 \mathrm{~cm}$ and $48 \mathrm{~cm} / 25 \mathrm{~cm}$. Naveen, a high yielding variety of Odisha showed a lesion length of $11-13 \mathrm{~cm}$ in isolate I, II, III, IV and $\mathrm{VI}$ and $5 \mathrm{~cm}$ in Isolate $\mathrm{V}$ and $\mathrm{VII}$, respectively, however, other variety Pooja showed $12-14 \mathrm{~cm}$ long lesion in isolate I, II, IV and VI and $10 \mathrm{~cm}$ in isolate III and IV. The improved HYV's of eastern India viz., Imp. Tapaswini, Imp. Lalat, Imp. Swarna and Imp. IR64 exhibited the lesion length of $1-4 \mathrm{~cm}$ in all isolates whereas high yielding varieties of North-east viz., CAU- R1 $(27 / 24 \mathrm{~cm})$, Shahsarang $(41 \mathrm{~cm} / 30 \mathrm{~cm})$, Lampnah $(40 \mathrm{~cm} / 28 \mathrm{~cm})$, Ranjit $(55 \mathrm{~cm} / 40 \mathrm{~cm})$, PD-10 $(47 \mathrm{~cm} / 35 \mathrm{~cm})$ and VL-82 $(48 \mathrm{~cm} /$ $31 \mathrm{~cm}$ ) showed different response to seven different isolates and ranged the lesion length from with reference to 10 to $18 \mathrm{~cm}$.

Diversity in level of virulence of Xoo Isolates, isolate II and VI were found more virulent in terms of leaf lesion length as compared to other isolates and the maximum lesion length of $18 \mathrm{~cm}$ was observed in isolate II and VI. The improved HYV's of Eastern India, i.e., Imp. Tapaswini, Imp. Lalat, Imp. Swarna and Imp. IR64 introgressed with xa5, xa13 and Xa21 genes were found resistant to all isolates. The HYV's of Eastern and Northeastern India i.e., Naveen, Pooja, CAU- R1, Shahsarang, Lampnah, Ranjit, PD-10 and VL-82 exhibited diverse behavior against different isolates of Xoo with moderately susceptible to susceptible reaction. While, the near isogenic lines (NILs) of IR24, IRBB60 (Xa4, xa5, xa13 and Xa21) and IRBB59 (xa5, $x a 13$ and $X a 21)$ showed resistance reaction to all the 7 isolates of Xoo, however, the susceptible check, TN-1 was found susceptible to all the isolate groups, except Isolate III, which showed moderate resistance (Table 7). NILs with two gene combinations, i.e., IRBB54 and IRBB55 were resistant and IRBB50, IRBB51, IRBB52 and IRBB53 showed moderate resistance. However, NILs with single gene such as IRBB4 (Xa4), IRBB13 (xa13), IRBB3 (xa3), IRBB5 (xa5), IRBB7 (Xa7), IRBB8 (xa8), IRBB10 (Xa10) and IRBB14 (Xa14) was moderately resistant to all isolates. Single gene cannot confer resistance to all the $X_{0 o}$ isolates (Shanti et al., 2001) and similar data was recorded in IRBB5 (xa5). As it confers resistance to isolate I, III, VII and moderately resistant to isolate II, IV, V, VII. Surprisingly, IRBB21 (Xa21) and Imp. PR114 (Xa38) was found resistant to all $X_{00}$ isolates due to $X_{a 21}$, a dominant gene is located on chromosome 11 of rice genome, confer 
Table 7: Bacterial blight disease reaction on near isogenic lines of Indica rice cultivars and distribution of pathotypes

\begin{tabular}{|c|c|c|c|c|c|c|c|}
\hline \multicolumn{8}{|c|}{ Pathotype and their prevailing location/states } \\
\hline Genotypes/ races & Isolate-I & Isolate-II & Isolate-III & Isolate-IV & Isolate-V & Isolate-VI & Isolate-VII \\
\hline $\begin{array}{l}\text { TN-1 (Negative } \\
\text { check) }\end{array}$ & S & S & MS & S & $S$ & S & S \\
\hline IRBB3 & MR & MR & MR & MR & MR & MR & MR \\
\hline IRBB4 & MR & MR & MR & MR & MR & MR & MR \\
\hline IRBB5 & $\mathrm{R}$ & MR & $\mathrm{R}$ & MR & MR & MR & $\mathrm{R}$ \\
\hline IRBB7 & MR & MR & MR & MR & MR & MR & MR \\
\hline IRBB8 & MR & MR & MR & MR & MR & MR & MR \\
\hline IRBB 10 & MR & MR & MR & MR & MR & MR & MR \\
\hline IRBB 13 & MR & MR & MR & MR & MR & MR & MR \\
\hline IRBB 14 & MR & MR & MR & MR & MR & MR & MR \\
\hline IRBB 21 & $\mathrm{R}$ & R & $\mathrm{R}$ & $\mathrm{R}$ & $\mathrm{R}$ & $\mathrm{R}$ & $\mathrm{R}$ \\
\hline IRBB 50 & MR & MR & MR & MR & MR & MR & MR \\
\hline IRBB 51 & MR & MR & MR & MR & MR & MR & MR \\
\hline IRBB 52 & MR & $\mathrm{R}$ & MR & $\mathrm{R}$ & MR & $\mathrm{R}$ & MR \\
\hline IRBB 53 & MR & MR & MR & MR & MR & MR & MR \\
\hline IRBB 54 & $\mathrm{R}$ & $\mathrm{R}$ & $\mathrm{R}$ & $\mathrm{R}$ & $\mathrm{R}$ & $\mathrm{R}$ & $\mathrm{R}$ \\
\hline IRBB 55 & $\mathrm{R}$ & $\mathrm{R}$ & $\mathrm{R}$ & $\mathrm{R}$ & $\mathrm{R}$ & $\mathrm{R}$ & $\mathrm{R}$ \\
\hline IRBB 56 & $\mathrm{R}$ & MR & $\mathrm{R}$ & MR & MR & MR & $\mathrm{R}$ \\
\hline IRBB 57 & $\mathrm{R}$ & $\mathrm{R}$ & $\mathrm{R}$ & $\mathrm{R}$ & $\mathrm{R}$ & $\mathrm{R}$ & $\mathrm{R}$ \\
\hline IRBB 58 & $\mathrm{R}$ & $\mathrm{R}$ & $\mathrm{R}$ & $\mathrm{R}$ & $\mathrm{R}$ & $\mathrm{R}$ & $\mathrm{R}$ \\
\hline IRBB 59 & $\mathrm{R}$ & $\mathrm{R}$ & $\mathrm{R}$ & $\mathrm{R}$ & $\mathrm{R}$ & $\mathrm{R}$ & $\mathrm{R}$ \\
\hline IRBB 60 & $\mathrm{R}$ & $\mathrm{R}$ & $\mathrm{R}$ & $\mathrm{R}$ & $\mathrm{R}$ & $\mathrm{R}$ & $\mathrm{R}$ \\
\hline Improved PR114 & $\mathrm{R}$ & $\mathrm{R}$ & $\mathrm{R}$ & $\mathrm{R}$ & $\mathrm{R}$ & $\mathrm{R}$ & $\mathrm{R}$ \\
\hline ImprovedLalat & $\mathrm{R}$ & $\mathrm{R}$ & $\mathrm{R}$ & $\mathrm{R}$ & $\mathrm{R}$ & $\mathrm{R}$ & $\mathrm{R}$ \\
\hline Imp.Tapaswani & $\mathrm{R}$ & $\mathrm{R}$ & $\mathrm{R}$ & $\mathrm{R}$ & $\mathrm{R}$ & $\mathrm{R}$ & $\mathrm{R}$ \\
\hline Improved IR64 & $\mathrm{R}$ & $\mathrm{R}$ & $\mathrm{R}$ & $\mathrm{R}$ & $\mathrm{R}$ & $\mathrm{R}$ & $\mathrm{R}$ \\
\hline Improved Swarna & $\mathrm{R}$ & $\mathrm{R}$ & $\mathrm{R}$ & $\mathrm{R}$ & $\mathrm{R}$ & $\mathrm{R}$ & $\mathrm{R}$ \\
\hline Naveen & MS & MS & MS & MS & MR & MS & MR \\
\hline Pooja & MS & MS & MR & MS & MR & MS & MR \\
\hline CAU-R1 & $S$ & MS & MS & $S$ & $S$ & $S$ & MS \\
\hline Shahsarang & MS & MS & MS & MR & MS & MS & MR \\
\hline Lampnah & MS & MS & MR & MR & MS & MS & MS \\
\hline Ranjit & MS & MS & MS & MS & MS & MS & MS \\
\hline PD-10 & MS & MS & MS & MS & MS & MS & MS \\
\hline VL-82 & MR & MS & MS & MR & MR & MS & MS \\
\hline
\end{tabular}

S: Susceptible; MS: Moderately susceptible; R: Resistant and MR: Moderately resistant

significant resistant solely or in combination with other $\mathrm{Xa}$ gene against a range of isolates; however, some isolates showed virulence and overcame Xa21 gene (Shanti et al., 2001). Resistance break of Xa21 gene has been reported by some highly virulent strains of India, Japan, Korea, Nepal and Sri Lanka (Goel et al., 1998; Adhikari et al., 1999). A newly identified Bacterial Blight resistance gene was identified from Oryza nivara acc. IRGC 81825, and mapped on chromosome $4 \mathrm{~L}$ in a 38.4-kb region (Bhasin et al., 2012). As it confers significant level of resistance to a range of $X_{0 o}$ isolates, $X_{a 38}$ gene was introgressed in Indian basmati rice variety 'PB1121'from donor parent PR114- Xa38 using a modified marker-assisted backcross (MABC) breeding scheme (Ellur et al., 2016).
To confer broad spectrum and durable resistance in rice cultivar, it is pre-requisite to select the best strategy for deployment of resistance gene and suitable donor. In the present study, Xa21 gene showed important component of resistance as a single gene as well as combination of two or three or four genes. This may be due to the effect of complementary interaction between different R- genes. Synergetic effect of other genes with Xa21 enhanced the resistance level with strong effect as low resistance was compensated by complementary R-gene that was alone moderately resistant or defeated by some virulent isolates. However, the xa13 gene is recessive in nature and present on chromosome 8. As a single gene, xa13 confer resistance to PXO99A a highly virulent isolate of Philippines and seven highly virulent isolate of India, Vietnam and Srilanka (Loan et al., 2006; 

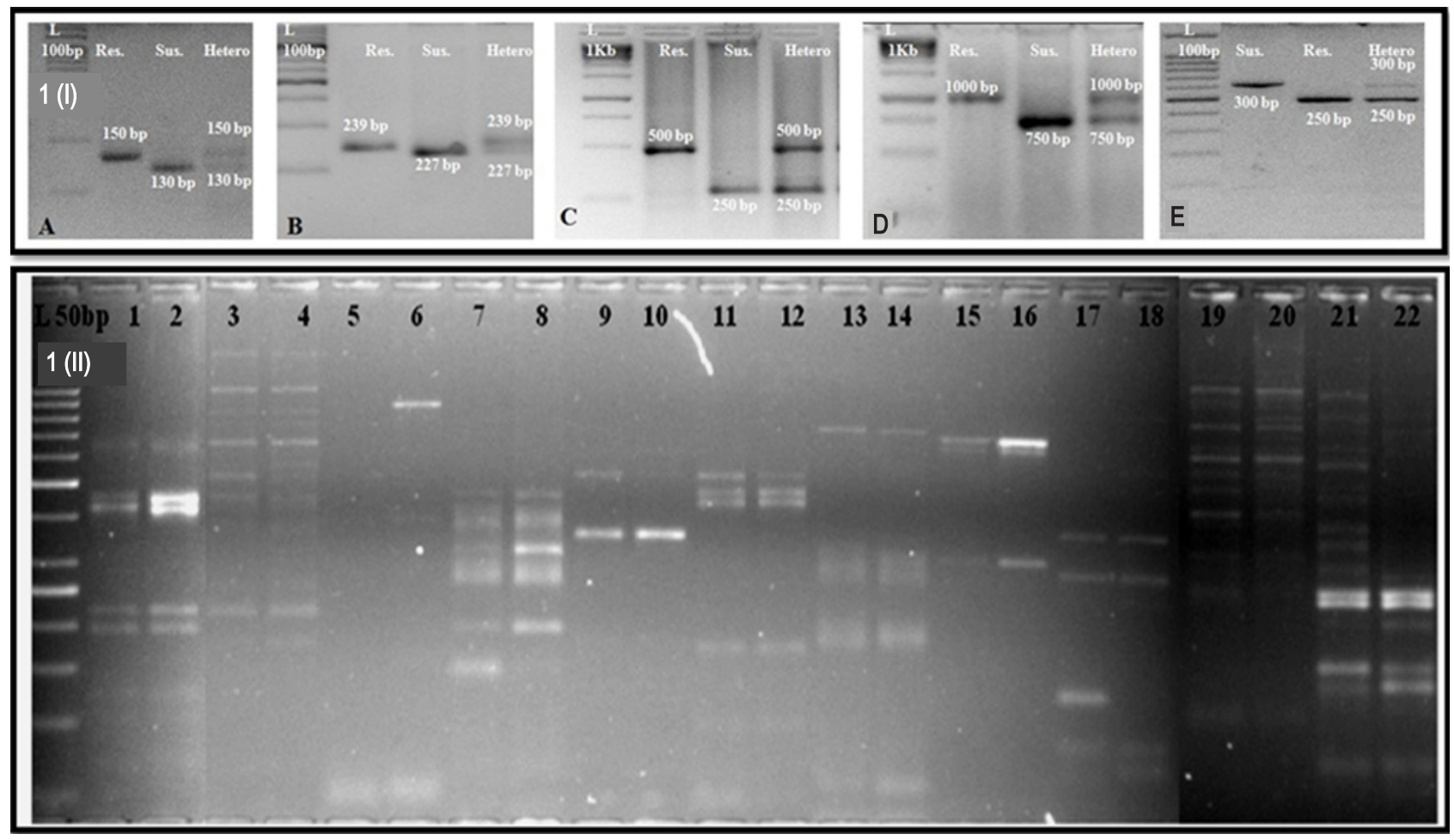

Fig. 1(I): Banding pattern of PCR product using (A) Npb181 (Xa4 gene), (B) RM122 (xa5 gene), (C) xa13-Prom (xa13 gene), (D) pTA248 (Xa21 gene), and (E) Os04g53050-1 (Xa38 gene). (II) Banding pattern of JEL1/JEL2 primer, used for grouping of isolated based on genetic diversity in $X_{00}$.

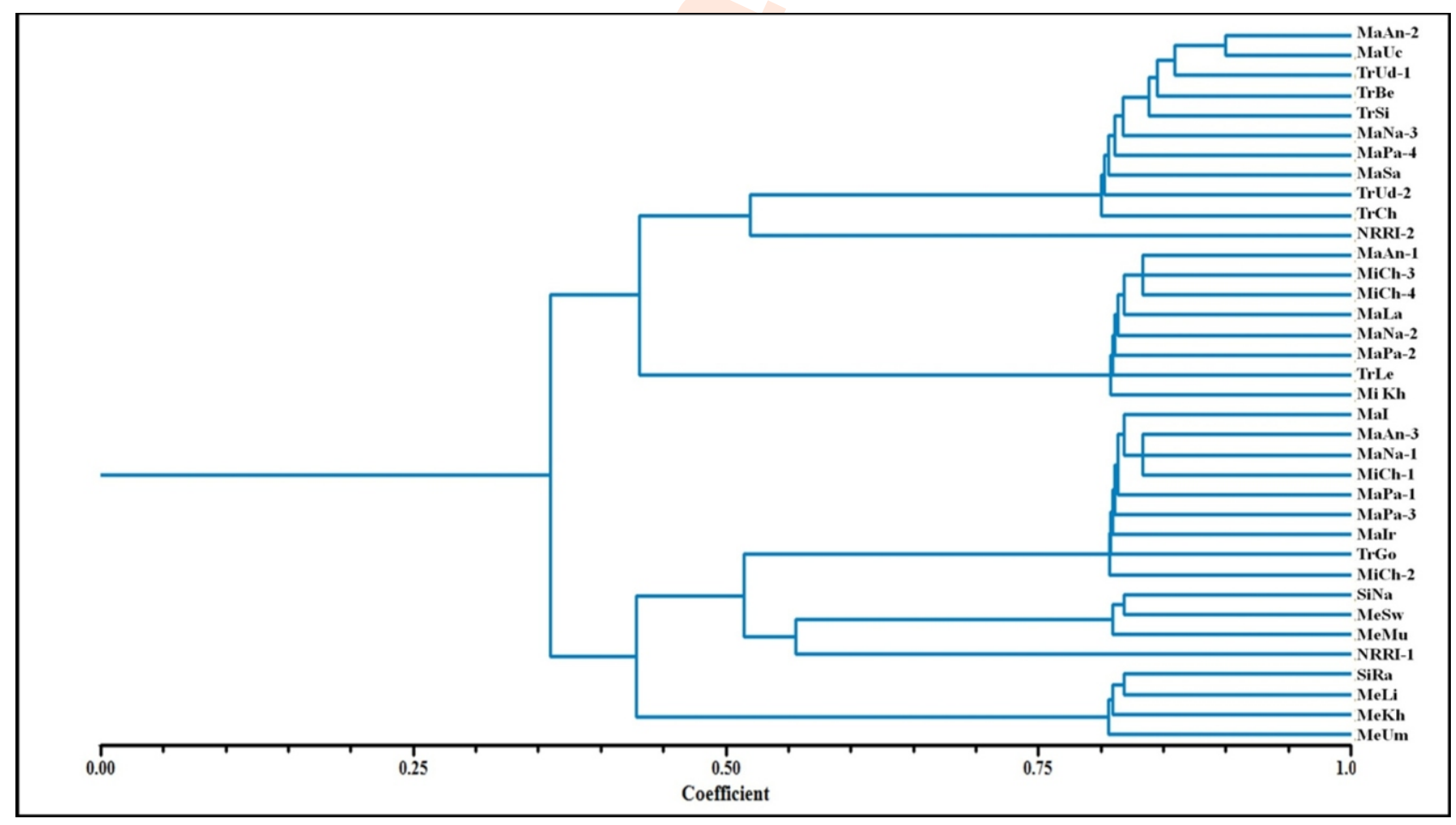

Fig. 2: Dendrogram showing genetic diversity and grouping of 36 Xoo isolates collected from Eastern and North-eastern India. 


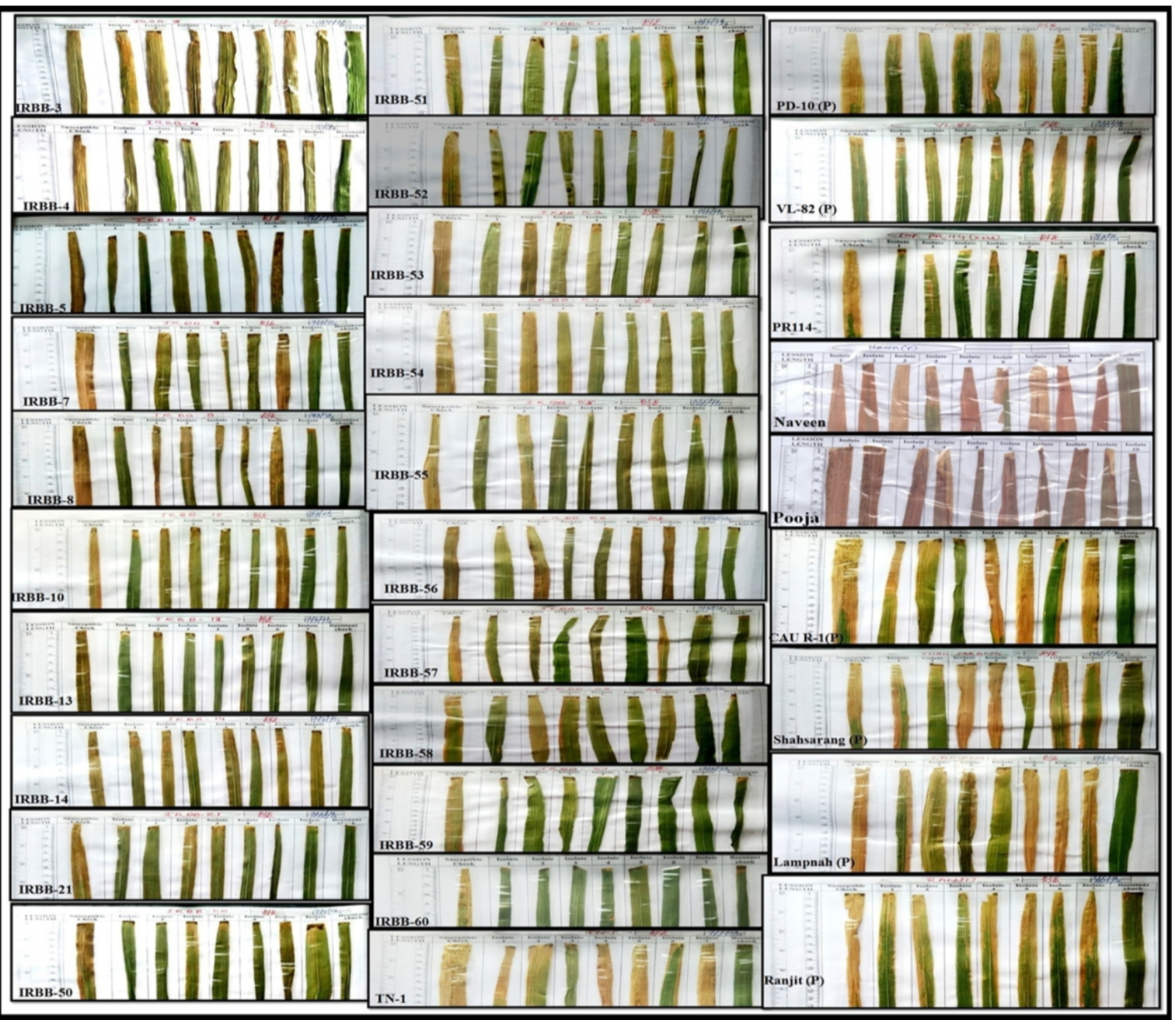

Fig. 3: BB disease Scoring; measurement of leaf lesion length in rice plant after 15 days of clip inoculation. All 34 genotypes were used for scoring, left side of each plates is $T N-1$ (negative check for BB) and right side of each plate is IRBB60 (positive check for BB).

Lore et al., 2011). The xa5 gene of rice is a recessive gene present on chromosome 5 and confers resistance to a range of Indian $X_{00}$ isolates. IRBB14 (Xa14) was susceptible to most of the Xoo isolates of Philippines and Punjab state of India (Lore et al., 2011). Other Bacterial Blight resistant single genes were not found resistant to any of the isolates. Pyramiding of two or more R-gene in different combinations gives a durable and broad-spectrum resistance to a range of $X_{00}$ isolates than single R-gene due to synergetic and complementary effect between R-genes (Narayanan et al., 2002; Singh et al., 2014; Singh et al., 2020).

In the present study, genotypes with four R-gene combinations such as IRBB60 (Xa4, xa5, xa13, Xa21) showed resistance to all 7 Xoo isolates. Similarly, IRBB59, which contain three R-genes (xa5, xa13, Xa21) also showed resistance to all 7 isolates. The performance of these two genotypes against all $7 X_{00}$ isolates was better as compared to other genotypes with different R-gene combination. However, improved rice varieties i.e. Tapaswini, Imp. Lalat, Imp. Swarna and Imp. IR64, which consisted similar R-gene combination were also found resistant as compared to IRBB60 and IRBB59, but the lesion length was higher than IRBB59 and IRBB60. Other NILs with three R-gene combination such as IRBB57 and IRBB58 showed resistance to all seven isolates but the $B B$ lesion length was slightly higher compare to IRBB60 and IRBB59. However, IRBB56 was found resistant to isolate I, III, VII and moderately 
resistant to Isolate II, IV, V and VI. Singh et al., (2002) also reported IRBB54 provide broad spectrum and durable resistance against several isolates of Korea and India, respectively. Similarly, NILs with two R-gene combination i.e., IRBB54 and IRBB55 were found resistant to all the isolates, however, IRBB50, IRBB51, IRBB52 and IRBB53 were moderately resistant to all isolates. $x a 5$ and $x a 13$ as best two recessive $R$-gene combination for effective resistance against all Xoo isolates of Punjab, India and Pakistan. (Goel et al., 1998, Singh et al., 2002; Khan et al., 2012) Yoshimura et al., 1995 also reported two genes combination for better resistance to $\mathrm{Xoo}$ Isolates of Philippine.

The outcome of the present study, provides significant implication for selecting suitable donors in rice having R-genes for durable and broad-spectrum Bacterial Blight disease resistance in Eastern and North-East Indian. Genetic diversity in Xoo isolates and their disease reaction against different $X_{a-}$ gene combination confirmed the presence of diverse $X_{00}$ races/isolates in India. Although all 10 R-genes i.e., Xa3, Xa4, xa5, Xa7, xa8, Xa10, xa13, Xa14, Xa21, Xa38 of BB were found useful against some specific isolates, except $X a 21$ and $X a 38$, and none of R-gene alone were able to confer resistance against all isolates studied. Variation in gene sequence in $X_{00}$ pathogens determines the level of pathogenicity in different geographical regions, however, in rice plants the level of resistance is determined by the presence of different $R$ gene combination and gene complementation.

These identified lines may be utilized as new identified potential donors for pyramiding of R-gene into locally adapted Bacterial Blight susceptible high yielding popular rice cultivars of different agro-ecological locations. After R- gene incorporation, these Bacterial Blight pyramided lines can reduce the yield penalty due to Bacterial Blight disease in a durable and broad-spectrum manner.

\section{Acknowledgments}

We acknowledge Department of Biotechnology, New Delhi, India for the financial support for the 'DBT-NER twinning project' and also the Director, ICAR-National Rice Research Institute (NRRI), Cuttack, Odisha, India and CAU-Manipur, Imphal, India for research assistance.

\section{Add-on Information}

Authors' contribution: J. Kumar: Conducted experiments and wrote the MS; A. Hussain: Collection of leaf samples; P. Singh: Analyze the data and wrote the MS; S.K.Y. Baksh: Inoculated the culture in field; M.K. Kar: Provide the facility at NRRI, Cuttack; A.K. Mukherjee: Provide the Xoo-culture at NRRI; N.R. Singh: Collected the disease infected sample; B. Sinha: Provide the Xoo-culture at CAU, Imphal; Pramesh Kh.: Collected the samples from field; N. Singh K.: Provide the Xoo-culture at CAU, Imphal and checked the MS; J.N. Reddy: Designed experiment and overall guidance.
Research content: The research content is original and has not been published elsewhere.

Ethical approval: NotApplicable.

Conflict of interest: The authors declare that there is no conflict of interest.

Data from other sources: NotApplicable.

Consent to publish: All authors agree to publish the paper in Journal of Environmental Biology.

\section{References}

Adhikari, T.B., T.W. Mew and J.E. Leach: Genotypic and pathotypic diversity in Xanthomonas oryzeae pv. oryzae in Nepal. Phytopath., 89, 687-694 (1999).

Bharathkumar, S., S. Gnanamanickam, J. Kumar, A. Bal, S.K.Y. Baksh, A. Das and D.K. Nayak: Differential disease reaction of rice pathogen Xanthomonas oryzae pv. oryzae prevailing In India on rice cultivar. Bioscan, 9, 1257-1262 (2014).

Bhasin, H., D. Bhatia, S. Raghuvanshi, S.L. Jagjit, K. Gurpreet, S.B. Kaur, V. Yogesh and K. Singh: New PCR-based sequence-tagged site marker for bacterial blight resistance gene Xa38 of rice. Mol. Breed., 30,607-613 (2012).

Blair, M.W. and S.R. McCouch: Microsatellite and sequence-tagged site markers diagnostic for the rice bacterial leaf blight resistance gene xa-5. Th. Appl. Genet., 95, 174-184 (1997).

Chen, S., X. Liu, L. Zing, D. Buying, J. Yang and X. Zhu: Genetic analysis and molecular mapping of a novel recessive gene xa34(t) for resistance against Xanthomonas oryzae pv. oryzae. Th. App. Genet., 122, 1331-1338 (2011).

Doyle, J.J. and J. L. Doyle: A rapid DNA isolation procedure for small quantities of fresh leaf tissue. Photoc. Bull., 19, 11-15 (1987)

Ellur, R.K., H. Aura, K.S. Gopal, P.K. Bhowmick, K.K. Vinod, M. Nagarajan, K.K. Mondal, N.K. Singh, K. Singh, K.V. Prabhu and A.K. Singh: Marker-aided Incorporation of $X a 38$, a novel bacterial blight resistance gene, in PB1121 and comparison of its resistance spectrum with xa13+Xa21. Sc. Repo., 6, 29188 (2016).

George, M.L.C., J.E. Leach and R.J. Nelson: DNA fingerprinting of Xanthomonas oryzae pv. Oryzeae using IS1112-based polymerase chain reaction. Int. Rice Res. Notes, 20, 30-37 (1995).

Goel, R.K., L. Kaur and R.G. Saini: Effectiveness of different Xa genes against Xanthomonas oryzeae pv. oryzae population causing bacterial blight of rice in Punjab (India). Rice Genet. Newsl., 15, 131 (1998).

Khan, J.A., M.I.A. Hafiz, S. Kamran, F.S. Ahmed, H. Shahida and M.B. Muhammad: Evaluation of resistance genes in rice against local isolates of Xanthomonas oryzae pv. Oryzae in Punjab province of Pakistan. Arch. Phytop. Pl. Prot., 45, 1826-1839 (2012).

Khush, G.S., D.J. Mackill and G.S. Sidhu: Breeding rice for resistance to bacterial blight. In: Proceeding of International Workshop on Bacterial Blight of Rice. International Rice Research Institute, Manila, Philippines., pp. 207-217 (1989).

Kauffman, H.E., A.P.K. Reddy, S.P.Y. Hsieh and S.D. Merca: An improved technique for evaluating resistance of rice varieties to Xanthomonas oryzae. Plant Dis. Rep., 57, 537-541 (1973).

Kim, S.M.: Identification and fine mapping of a new resistance gene,

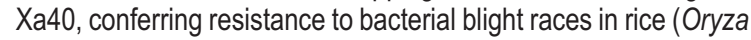


sativa L.). Th. App. Genet., 128,1933-1943 (2015).

Kim, S.M., R.F. Reinke and R.M. Sundaram: A novel resistance gene for bacterial blight in rice, $X_{a} 43(t)$ identified by GWAS, confirmed by QTL mapping using a bi-parental population. PLOS ONE,14, e0211775 (2019).

Kumar, M., R.P. Singh, O.N. Singh, P. Singh,P. Arsode, Namrata, M. Chaudhary, D. Jena, V. Singh, D. Rout, A.K. Mukherjee, S. Samantaray and R.L. Verma: Genetic analysis for bacterial blight resistance in Indica rice (Oryza sativa L.) cultivars. Oryza: An. Int. J., 56, 247-255 (2019).

Loan, L.E., V.T.T. Ngan and P.V. Du: Preliminary evaluation on resistance genes against rice bacterial leaf blight in Can Tho Province Vietnam. Omonrice, 14, 44-47 (2006).

Lore, J.S., Y. Vial, M.S. Hunjan, R.K. Goel, T.S. Bharaj and G.L. Raina: Genotypic and pathotypic diversity of Xanthomonas oryzae pv. oryzae, the cause of bacterial blight of rice in Punjab state of India. J. Phytop., 159, 479-487 (2011).

Manju, V. Kaur, K. Sharma and A. Kumar: Identification of promising sources for drought tolerance in cultivated and wild species germplasm of barley based on root architecture. J. Environ. Biol., 40,309-315(2019).

Mondal, K.K., B.R. Meena, A. Junaid, G. Verma, C. Mani, D. Majumder, M. Khicher, S. Kumar and S. Banik: Pathotyping and genetic screening of type III effectors in Indian strains of Xanthomonas oryzae pv. oryzae causing bacterial leaf blight of rice. Phys. Mol. PI. Path., 86, 98-106 (2014).

Narayanan, N.N., N. Baisakh, C.M. Vera-Cruz, S.S. Gnanamanickam, K. Datta and S.K. Datta: Molecular breeding for the development of blast and bacterial blight resistance in rice cv. IR50. Crop Sci., 42, 2072-2079 (2002).

Natrajkumar, P., K. Sujatha, G.S. Laha, K. Srinivasarao, B. Mishra, B.C. Viraktamath, Y. Hari, C.S. Reddy, S.M. Balachandran, T. Ram, M. Sheshumadhav, N. Shobharani, C.N. Neeraja, G. Ashokreddy, H. Shaik and R.M. Sundaram: Identification and fine-mapping of Xa33, a novel gene for resistance to Xanthomonas oryzae pv. oryzae. Phytoplankton, 102, 222-228 (2012).

Onasanya, A., M.M. Ekperigin, F.E. Nwilene, Y. Sere and R.O. Onasanya: Two pathotypes of Xanthomonas oryzae pv. oryzae virulence identified in West Africa. Curr. Res. Bacter., 2, 22-35(2009).

Ou, S.H.: Rice Diseases. Commonwealth Mycological Institute, Kew, Surrey, United Kingdom (1985).

Pandey, A.K., A.K. Singh, P. Singh, R.P. Vyas, R.K. Singh and H. Bhandari: Characterization and varietal identification of pigeonpea (Cajanus cajan L. Millsp) genotypes through SDS-PAGE based electrophoresis of seed protein. Legume Research:An Inter. J., 43, 165-171 (2020)

Ronald, P.C., B. Albano, R. Tabien, L. Abenes, K.S. Wu, S. Couch and S.D. Tanksley: Genetic and physical analysis of the rice bacterial blight disease resistance locus, Xa21. Mol. Genom. Genet., 236, 113-120 (1992)

Shanti, M.L., M.L.C. George, C.M. Vera Cruz, M.A. Bernardo, R.J. Nelson, H. Leung, J.N. Reddy and R. Sridhar: Identification of resistance genes effective against rice bacterial blight pathogen in Eastern India. Plant Dis., 85, 506-512 (2001).

Singh, G.P., M.K. Srivastava, R.V. Singh and R.M. Singh: Variation and qualitative losses caused by bacterial blight in different rice varieties. Ind. Phytop., 30, 180-185 (1977).

Singh, P., R.L. Verma, R.S. Singh, R.P. Singh, H.B. Singh, P. Arsode, M. Kumar and M. K. Singh: Biotic stress management in rice (Oryza sativa L.) through conventional and molecular approaches. In.: New Frontiers in Stress Management for Durable Agriculture (Eds.: A. Rakshit, H. Singh, A.K. Singh, U.S. Singh and L. Fraceto). Springer, Singapore (2020). https://doi.org/ 10.1007/978-981-151322-0_30

Singh, P., R.P. Singh, H.B. Singh, O.N. Singh, S. Somantarai, M.K. Singh and H.K. Jaiswal: Inheritance of bacterial leaf blight (Xanthomonas oryzae pv. oryzae) resistance in Indica rice cultivar HUR 4-3. I. J. Agr. Env. Biot., 7, 777-785 (2014).

Singh, P., R.P. Singh, H.B. Singh, O.N. Singh, R.L. Verma, J.L. Katara and C. Mohapatra: Genetics of resistance for bacterial leaf blight in high yielding popular Indica rice (Oryza sativa L.) cultivar of Eastern Uttar Pradesh. J. New Agricul., 25, 1-8 (2014).

Singh, P., R.P. Singh, R.L. Verma, H.B. Singh, S. Singh and O.N. Singh: Inheritance of bacterial leaf blight (Xanthomonas oryzeae pv. oryzae) resistance in popular Indica rice cultivar HUBR 10-9. I. J. Agr. Env. Biot., 11, 01-09 (2018).

Singh, S., M. Sodhi, Y. Vial, M.L.C. George, G.S. Bala, G.S. Mangat, M. Garg, J.S. Sidhu and H.S. Dhaliwal: DNA fingerprinting and virulence analysis of Xanthomonas oryzeae pv. oryzae isolates from Punjab, Northern India. Euphy., 130, 107-115 (2002).

Sneath, P.H.A. and R.R. Sokal: Numerical Taxonomy: The Principal and Practice of Numerical Taxonomy. W. H. Freeman and Co. San Francisco., 573 pages (1973).

Suh, J.P., J. Ji-Ung, J.U. Noh, T.H. Cho, Y.C. Park, S.H. Park, H.S. MunSik, M.S. Shin, C.K. Kim and K.K. Jena: Development of breeding lines with three pyramided resistance genes that confer broadspectrum bacterial blight resistance and their molecular analysis in rice. Rice, 6, 5(2013)

Verma, R.L., S. Singh, P. Singh, V. Kumar, S.P. Singh, S. Singh, S. Samantray and O.N. Singh: Genetic purity assessment of Indica rice hybrids (Oryza sativa L.) through grow-out test (GOT) and DNA fingerprinting. J. Environ. Bio., 38, 1321-1331 (2017).

Wang, O.L., W.Y. Song, L.L. Chen, R. Ruan, S. Sidesis and P.C. Ronald: Resistance spectrum, race specificity and expression of the Xa21 gene family. IRRN., 21, 45-46 (1996).

Yamamoto, T., H.R. Hifni, M. Muchmud, T. Nishizawa and D.M. Tantera: Variation in pathogenicity of Xanthomonas oryzae pv. oryzae (Uyeda et Ishiyama) Dowson and resistance of rice varieties to the pathogen. Contr. Centr. Res. Ins. Agric. Bogo., 28, 22 (1977).

Yoshimura, S., A. Yoshimura, N. Iwata, S.R. McCouch, M.L. Abenes, M.R. Baraoidan, T.W. Mew and R.J. Nelson: Tagging and combining bacterial blight resistance genes in rice using RAPD and RFLP markers. Mol. Breed., 1, 375-387 (1995). 